\title{
HERBASPIRILLUM SEROPEDICAE AND SUGARCANE ENDOPHYTIC INTERACTION INVESTIGATED BY USING HIGH PRESSURE FREEZING ELECTRON MICROSCOPY
}

\author{
Lúcia Gracinda da Silva; Flávio Costa Miguens; Fabio Lopes Olivares*
}

Laboratório de Biologia Celular e Tecidual, Centro de Biociências e Biotecnologia, Universidade Estadual do Norte Fluminense Darcy Ribeiro, Campos dos Goytacazes, RJ, Brasil.

This paper corresponds to an "extended abstract" selected for oral presentation in the $22^{\text {nd }}$ Brazilian Congress of Microbiology, held in Florianópolis, SC, Brazil, in November 17-20, 2003

\begin{abstract}
The interaction between sugar cane plantlets and H. seropedicae was investigated using High Pressure Freezing followed by Freeze Substitution. Microscopical observation showed consistent differences between this approaches when compared with the conventional preparation, specially related to appearance of the bacteria cell and the endophytic attachment to the host cell wall.
\end{abstract}

Key words: H. seropedicae, high pressure freezing, endophytic interaction.

\section{INTRODUCTION}

Herbaspirillum seropedicae are Gram-negative bacteria capable of fixing nitrogen and promoting plant growth in different grasses $(1,4,8)$. Ecological studies have shown that these bacteria can be isolated from the interior of roots, stems and leaves of many grasses, but never from soil samples (7). In addition, studies involving light and transmission electron microscopy have clearly demonstrated the endophytic nature of the plant-bacteria interaction $(5,9)$. At structural level, the interactions between Herbaspirillum seropedicae and sugar cane plants have been receiving attention over the last 13 years. Studies based on chemically fixed samples of roots and shoots have demonstrated that the endophytic bacteria colonize randomly as single cells or micro colonies in the apoplast (intercellular spaces, cell wall and xylem lumen) as cited by James and Olivares (5). In the present study, we used High Pressure Freezing Technique (HPF) followed by Freeze Substitution to investigate the sugar cane $/ \mathrm{H}$. seropedicae interaction at microscopic level.

\section{MATERIALS AND METHODS}

\section{Bacterial strains and growth conditions}

The bacterial strain used in this study was Herbaspirillum seropedicae (BR11175), grown overnight at $30^{\circ} \mathrm{C}$ and $120 \mathrm{rpm}$ in Dyg's medium.

\section{Plant Material}

Micro-propagated plantlets of sugar cane (3) var. RB72454 were grown in a modified $2 \%$ sucrose MS medium (6) and inoculated with $0.1 \mathrm{~mL}$ of the suspension containing $10^{8}$ cell. $\mathrm{mL}^{-1}$.

\section{Cryo-technique preparation and microscopy evaluation}

Plantlets were harvested one week after inoculation, and small pieces of roots and leaves $(0.1-0.6 \mathrm{~mm})$ were carefully colleted in filter paper and inserted into the support of aluminium covered with hexadecane (1-hexadecene, Fluka, Buchs, Switzerland). The freezing process was performed at $-196^{\circ} \mathrm{C}$ and at 2,100 Bar (HPM 010 - High Pressure Freezing Machine, Baltec). The frozen samples were transferred to the Freezer Substitution

*Corresponding author. Mailing address: Av. Alberto Lamego, 2000, Parque Califórnia, Campos dos Goytacazes. 28013-602, Rio de Janeiro, RJ, Brasil. Fax (+5522) 2726-1514. E-mail: fabioliv@uenf.br 
Apparatus (Baltec) and, then fixed with $2 \%$ osmium tetroxide in $100 \%$ acetone solution for $24 \mathrm{~h}\left(-85^{\circ} \mathrm{C} / 8 \mathrm{~h},-60^{\circ} \mathrm{C} / 8 \mathrm{~h}\right.$ e $\left.-20^{\circ} \mathrm{C} / 8 \mathrm{~h}\right)$. Samples were washed twice (acetone) and infiltrated with Sppur resin. Polymerised blocks were sectioned, stained and viewed using a transmission electron microscope (TEM) (Zeiss EM 900) operating at $80 \mathrm{KV}$ under standard conditions.

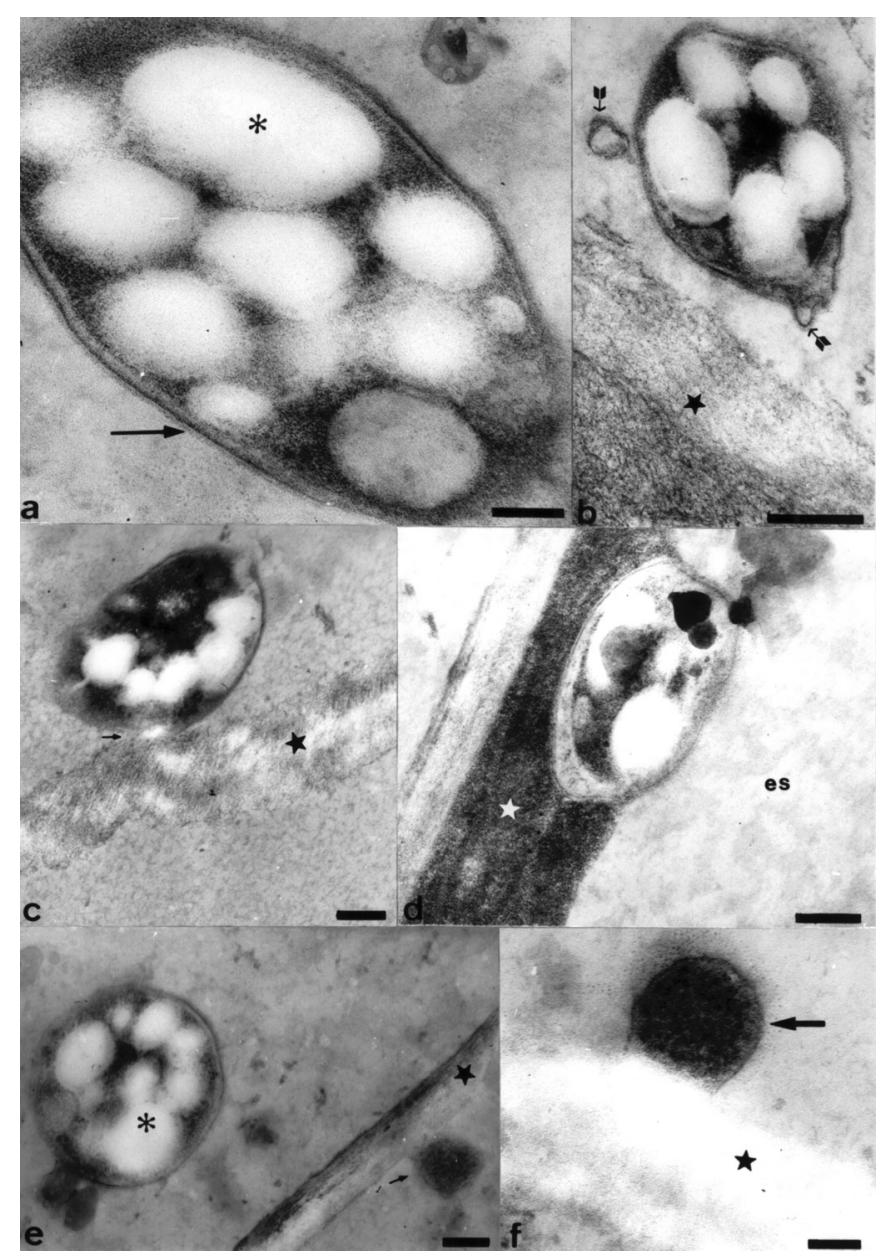

Figure 1. H. seropedicae strain BR11175 colonizing the apoplast close to vascular parenchyma cells of the leaf tissue of the sugarcane plants (var. RB72454). Figure a: Note various and large PHB granules (asterisk) in the cytoplasm of non-adhered bacteria. Bacteria cell wall (arrow). Figure b: Bacteria close to the plant cell wall (star); cell wall structures (arrows). Figure c: Bacteria adhered to plant cell wall. Note that at the adhesion site both cell walls limits can not be identified (arrow). Figure d: Bacteria immersed in plant cell wall (star). Figure e: Bacteria close to the plant cell wall (star). Multivesicular body in the periphery of plant cytoplasm (arrow). Figure f: Fusion of the multivesicular body with plant cell membrane. Legend: asterisk $=$ poly- $\beta$ hydroxybuyrate; es = extracellular space. Magnifications: Bars = a, b-100 nm; c, d ,e-150 nm; f- $120 \mathrm{~nm}$.

\section{RESULTS AND DISCUSSION}

Microscopic observations showed significant differences between the cryo-technique approaches as compared with the conventional preparation, specially in relation to the appearance of the bacteria cell (Figs. 1 and 2) and the type of the endophytic attachment to the host cell wall (Figs. 1c, 1d, 2d, 2e and 2f). $H$.

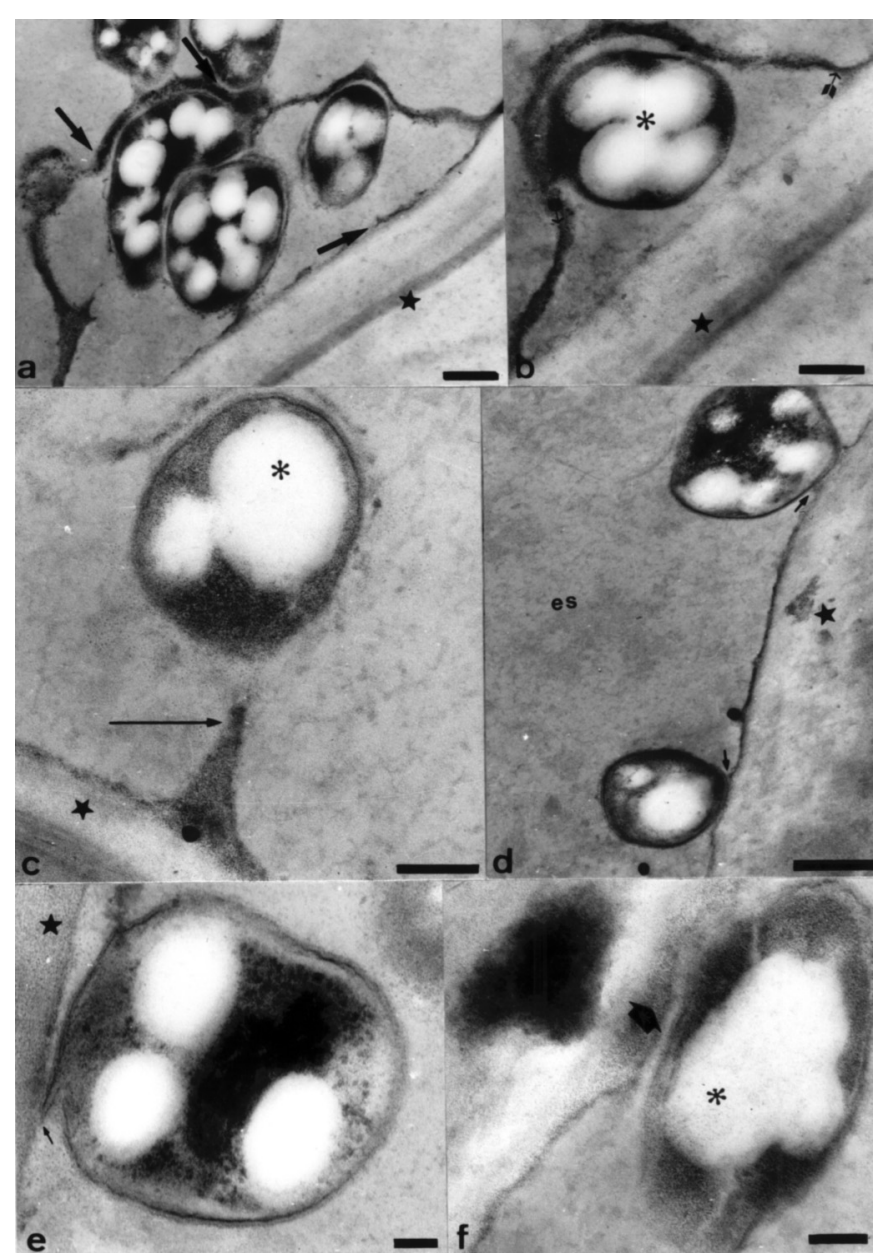

Figure 2. H. seropedicae strain BR11175 colonizing the apoplast of cortical cells of the root tissue of the sugarcane plants (var. RB72454). Figure a and b: Bacteria near the plant cell wall (star) involved by amorphous material (arrow). Figure c: Bacterium attached to the plant cell wall (star) by stalk electron-dense material (arrow). Figure d: Bacterium in close contact to the plant cell wall. Note alterations in both cell walls in the adhesion site (arrows). Figure e: Bacterium protrusion (arrow) toward to the plant cell wall (star) in the adhesion site. Figure f: Bacterium adhered with the plant cell wall (star). Note that the limit of the both cell walls is not clear (arrow). Legend: asterisk $=$ poly- $\beta$ hydroxybuyrate; es: extracellular space. Magnifications: Bars = a, d- $0.25 \mu \mathrm{m} ; \mathrm{b}-150 \mathrm{~nm} ; \mathrm{c}-0.75 \mu \mathrm{m} ; \mathrm{e}, \mathrm{f}-100 \mathrm{~nm}$. 
seropedicae was localized as a single cell or a micro colony inside the apoplast of leaves. Bacteria were also found inside apparently dead vascular parenchyma cells. Root cortex apoplast showed bacteria surrounded by an amorphous matrix of unknown composition (Figs. 2a and 2b), as well as adhered to the plant cell wall by a stalk of electron-dense material (Fig. 2c). Similar results were observed for the first time by Gyaneshwar (2). In both roots and leaves, bacterial cytoplasm has shown numerous poly- $\beta$-hydroxybutyrate (PHB) granules. At adhesion sites both bacteria and plant cell walls showed altered aspects (Figs. 1c, 2d, 2e and 2f) and bacterial protrusions could be observed (Fig. 2e). In roots, multivesicular bodies were observed close to the adhesion sites (Figs. 1e and 1f). In conclusion, high-pressure technique was an essential tool to obtain morphological data demonstrating alterations in both bacteria and plant cells during Herbaspirilum seropedicae / sugar cane interactions.

\section{ACKNOWLEDGEMENTS}

This work was supported by CNPq, FAPERJ, FENORTE, PRONEX.

\section{RESUMO}

\section{Uso da técnica de congelamento por alta pressão no estudo da interação endofítica de Herbaspirillum seropedicae e cana-de-açúcar}

A interação entre plântulas de cana-de-açúcar e H. seropedicae foi investigada pelo uso da técnica de congelamento por alta pressão seguida de criosubstituição. Observações microscópicas evidenciaram diferenças marcantes entre esta técnica e preparações convencionais, especialmente relacionadas a ultraestrutura da bactéria e às estruturas envolvidas na adesão à superfície da parede celular da planta hospedeira.

Palavras-chave: $H$. seropedicae, congelamento por alta pressão, interação endofítica.

\section{REFERENCES}

1. Balbani, J.I.; Baldani, V.L.D.; Seldin, L.; Döbereiner, J Characterization of Herbaspirilum seropedicae gen. nov. sp. nov., a root-associated nitrogen fixing bacterium. Int. J. Syst. Bacteriol. 36:86-93, 1986.

2. Gyaneshwar, P.; James, E.K.; Mathan, N.; Reddy, P.M.; ReinholdHurek, B.; Ladha, J.K. Endophytic colonization of rice by a diazotrophic strain of Serratia marcescens. J. Bacteriol., 183(8):2634-2645, 2001.

3. Hendre, R.R.; Iyer, R.S.; Kotwalm, M; Kluspe, S.S.; Mascarenhas, A.F. Rapid multiplication of sugar cane by tissue culture. Sugar Cane, 1:5-8, 1983.

4. James, E.K.; Gyaneshwar, P.; Mathan, N.; Barraquio, Q.L.; Reddy, P.M.; Iannetta, P.P.M.; Olivares, F.L.; Ladha, J.K. Infection and colonization of rice seedlings by the plant growth-promoting bacterium Herbaspirillum seropedicae Z67. Mol. Plant Microbe Interact., 15(9):894-906, 2002.

5. James, E.K.; Olivares, F.L. Infection and colonization of sugar cane and other graminaceous plants by endophytic diazotrophs Critic Rev. Plant Sci., 17(1):77-119, 1998.

6. Murashigue, T.; Skoog, F.A. Revised medium for rapid growth and bioassay with Tobaco tissue cultures. Physiol Plant., 15:47-497, 1962

7. Olivares, F.L.; Baldani, V.L.D.; Reis, V.M.; Baldani, J.I.; Döbereiner, J Occurrence of the endophytic diazotrophs Herbaspirillum spp. In roots, stems, and leaves, predominantly of Gramineae. Biol. Fertil. Soils., 21:197-200, 1996.

8. Oliveira, A.L.M.; Urquiaga, S.; Döbereiner, J.; Baldani, J.I. The effect of inoculating endophytic $\mathrm{N}_{2}$-fixing bacteria on micropropagated sugarcane plants. Plant Soil., 242(2):205-215, 2002.

9. Roncato-Maccari, L.D.B.; Ramos, H.J.O.; Pedrosa, F.O.; Alquini, Y.; Chubatsu, L.S.; Yates, M.G.; Rigo, L.U.; Steffens, M.B.R.; Souza, E.M. Root colonization, systemic spreading and contribution of Herbaspirillum seropedicae to growth of rice seedling. Symbiosis, 35(1-3):261-270, 2003. 